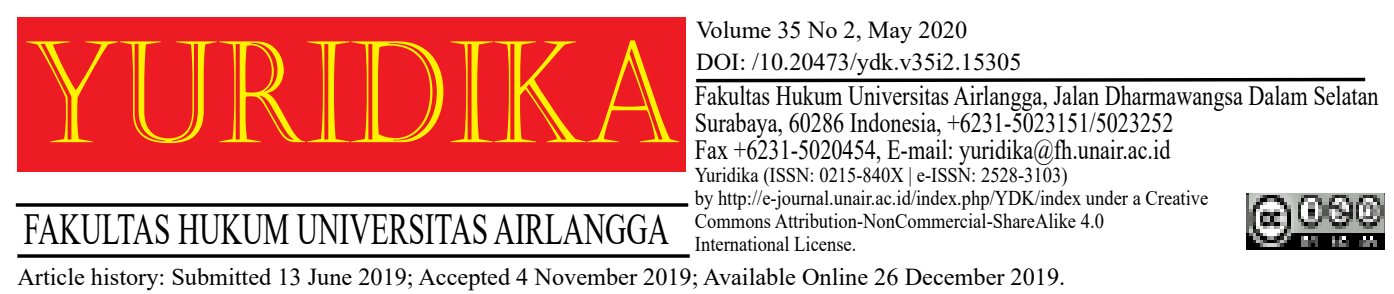

\title{
Payment of Compensation for Officials Who Did Not Implement the Decision of the State Administrative Court
}

\author{
Aries Saputro \\ arieskorpri@gmail.com \\ Sidoarjo District Government
}

\begin{abstract}
Unlawful Acts by the Agency and/or Government Official (onrechtmatige overheidsdaad) carried out in exercising their authority, which may result in the public, individuals and private legal entities to bring a civil suit to the District Court, to obtain compensation. Meanwhile, the public, individuals or legal entities may request an administrative claim for the issuance of a State Administration Decree by a Government Official to the State Administrative Court. The Court's Decision is a representation of legal considerations by the Judge which is recognized as "res judicata pro veritate habetur" which means that the judge's decision is considered to be correct and immediate. In the District Court District for Officers who do not implement the Decision, an execution will be carried out, if there is an execution from the court in this case, it is due to the trial that the implementation of the Decision is carried out in its leadership capacity in the PTUN Decision Domain, in the civil domain in the Court. If the Government Official sued loses, compensation must go through the Government Budget for the Community, Individuals and Legal Entities and vice versa. However, the Government Officials specifically against the PTUN Decision won back sometimes when they were not ready to implement the Court's Decision as it was done by force. Because the efforts carried out are contained within, as is the case, the decision cannot be carried out and handled by the law contained therein.
\end{abstract}

Keywords: Unlawful Acts By Officials; Lawsuit; Verdict; Execution.

\section{Introduction}

Historically, State Administrative Court has existed since 1986, with the enactment of Law Number 5 of 1986 concerning State Administrative Court on 29 December 1986 and on the basis of Government Regulation No. 7 of 1991 the government established the coming into force of the State Administrative Court effective January 14, 1991. Currently, Law Number 5 of 1986 has been amended by Law Number 9 of 2004 concerning Amendment to Law Number 5 of 1986 concerning 
State Administrative Court and amended again by Law Number 51 of 2009 concerning the Second Amendment to Law Number 5 of 1986 concerning State Administrative Court. However, the aspiration or desire to form a State Administrative Court has actually been initiated since 1946 . This is evidenced by the formation of the Draft Law on Case Events in Government Administration Matters. ${ }^{1}$

If it is demanded from the basic idea of its formation, according to the government's explanation before the plenary session of the House of Representatives (DPR) when delivering its planned law of April 29, 1986, the State Administrative Court was formed in resolving disputes between the government and its citizens as a result of actions government actions (bestuurshandelingen) which are considered to violate the rights of citizens with the aim of providing legal protection to the people (both regarding individual or individual rights and community rights). Thus, the formation of a judicial body that is given the power to adjudicate government officials who use the authority of their government by violating the rights of citizens who aim to provide legal protection to their citizens is a step forward in order to realize the rule of law. Government Actions are formulated as a State Administration Decree which is the object of a dispute in the State Administrative Court, as normatively regulated in article 1 paragraph 9 of Law Number 51 Year 2009 Concerning the Second Amendment to Law Number 5 of 1986 concerning State Administrative Court reads " The Decree of State Administration is a written stipulation issued by a state administration body or official containing legal action on state administration based on applicable legislation, which is concrete, individual, and final, which causes legal consequences for a person or a legal entity. "Regarding the way to test the KTUN, is the mechanism in Article 53 of Law Number 9 of 2004 concerning Amendment to Law Number 5 of 1986 concerning State Administrative Court that reads "(1) A person or civil legal entity that feels its interests are impaired by an Administrative Decree The State Enterprises may submit a written claim to the competent court which contains demands that the disputed State Administrative

1 Wirjono Projodikoro, Asas-Asas Ilmu Negara Dan Politik (Eresco 1971).[42]. 
Decree be declared invalid or invalid, with or without a claim for compensation and/or rehabilitation (2). Reasons that can be used in the lawsuit as referred to in paragraph (1) is; a. The State Administrative Decision that is sued is contrary to the applicable laws and regulations, b. The State Administrative Decision sued contradicts the general principles of good governance". ${ }^{2}$

In general, the Peratun decision is condemnatoir, declaratory and constitutief with the following explanation: if a lawsuit is granted, then the Peratun decision will contain a statement of what is the law and at the same time can nullify the legal situation and create a new legal state (constitutief). In canceling a KTUN (or TUN action), the decision is declaratoir because it states that the object of the dispute was issued by an unauthorized official (illegal). If the object of the dispute is declared invalid (procedural or substance flawed), the decision creates a new legal state (constitutief). The conditional nature of a decision, for example, is when a defendant is required (ordered) to revoke or is also required to issue a new KTUN in addition to being sentenced to pay the court fee. ${ }^{3}$

If the lawsuit has reached the TUN Court Decision which has permanent legal force (In Kracht Van Gewijsde). The government sometimes does not carry out decisions voluntarily because from the point of executing the execution of the PTUN Decision there is no threatening forceful effort, as well as in the Lawsuit Against the Law in the District Court, decisions that have permanent legal force also sometimes cannot be executed because in Article 50 Law Number 1 of 2004 concerning the State Treasury (hereinafter referred to as the "State Treasury Law"), which states: Any party is prohibited from confiscating: a. Money or securities belonging to the state/region both within a Government agency or a party third; $b$. Money that must be deposited by a third party to the country/region; c. Movable goods belonging to the state/region both within a Government institution and in

2 Paulus Efendi Lotulung, Lintasan Sejarah Dan Gerak Dinamika Peradilan Tata Usaha Negara (PERATUN) Di Mata Paulus Effendi Lotulung (Salemba Humanika 2013).[72].

3 Enrico Simanjuntak, Hukum Acara Pradilan Tata Usaha Negara Transformasi \& Refleksi (Sinar Grafika 2018).[258]. 
a third party; immovable goods and other property rights belonging to the state/ region; e. Goods which are belonging to third parties controlled by the state/region that are required to carry out governmental tasks.

The application of forced measures in the form of forced payment of money (dwangsom) and/or administrative sanctions for officials who do not carry out state administrative court decisions with permanent legal force (in kracht van gewijsde) encountered many problems. This is because there is no way out that can provide space for the plaintiff to get his right back that was harmed by the issuance of a state administration decision (beschikking). When forced payment of money (dwangsom) is implemented and it turns out that the official concerned is not willing to carry out forced payment of money (dwangsom) voluntarily even though confiscation of state assets cannot be carried out, as stated in the provisions of Article 50 of Law Number 1 the Year 2004 concerning State Treasury. Thus, the punishment in the form of forced payment of money (dwangsom) becomes meaningless, because it does not have a strong force. ${ }^{4}$

However, even though the establishment of the State Administrative Court is a developed idea in order to realize a modern legal state. But the problem for almost 30 (thirty) years of the existence of the State Administrative Court is the implementation (executie) of the decision of the State Administrative Court. ${ }^{5}$

Obstacles to the implementation of court decisions are not simple because in theory the law itself indirectly provides protection for the government. First: The legal factors themselves Interference with law enforcement originating from the law is likely caused by:

a. Non-adherence to the principles of enactment of the law resulting in the absence of legal certainty,

b. The absence of implementing regulations that are needed to put the law,

c. The unclear meaning of the words in the law which results in confusion in the interpretation and application.

4 Mohammad Afifudin Soleh, 'Eksekusi Terhadap Putusan Pengadilan Tata Usaha Negara Yang Berkekuatan Hukum Tetap’ (2018) 39 Mimbar Keadilan Jurnal Ilmu Hukum.[18-46].

5 ibid.[20]. 
Secondly; Law enforcement factors. Namely the parties who form or apply the law. Sociologically, every law enforcement has a status and role. Problems arising from law enforcement factors are the application of the role of law enforcement. Obstacles that need to be overcome are, among others: a. Limited ability to place oneself in the role of other parties with whom he interacts, $b$. The level of aspiration is relatively not high, c. Excitement is very limited to think about the future, so it is very difficult to make a projection, $d$. The absence of the ability to postpone the satisfaction of certain needs, especially material needs, e. The lack of innovative power is actually a conservatism partner. Third; Factors of facilities or facilities that support law enforcement. Facilities or facilities have a very important role in law enforcement. Without secondary and tertiary legal material. The technique of collecting legal material uses documentary studies which are studies of studying various documents. ${ }^{6}$

\section{Forced Efforts and Administrative Sanctions for Officials Who do Not Implement the PTUN Decision}

In the period before the enactment of Law Number 30 the Year 2014 Regarding Government Administration. The decision of the State Administrative Court contains the rules as stipulated in Article 97 paragraph 7 of Law Number 5 of 1986 concerning State Administrative Court The Judgment of the Court can be in the form of:

a. The lawsuit was rejected;

b. The lawsuit was granted;

c. The lawsuit not accepted;

d. Lawsuit fall.

Paragraph (8) In the event that a lawsuit is granted, then the Court's ruling may determine the obligation which must be carried out by the State Administration Agency or Officer who issued the State Administration Decree. Paragraph (9) The obligation referred to in paragraph (8) is in the form of:

6 Lubna, 'Efforts To Force The Implementation Of The Court Ruling The Country In Providing Legal Protection To The Community’ (2015) 168 Ius Kajian Hukum Dan Keadilan. 
a. Revocation of the State Administration Decree concerned; or

b. Revocation of the relevant State Administration Decree and issue a new State Administratiom Decree; or

c. The issuance of a State Administration Decree in the case of a lawsuit is based on Article 3.

Whereas if legal remedies are not submitted, then the decision has permanent legal force, by having permanent legal force, a decision must be carried out according to his permission. Regarding the verdict that requires revoking KTUN as Article 97 paragraph 9 letter a of Law Number 5 of 1986 concerning State Administrative Court if the Government Official does not revoke the Decision shall be canceled with a period of time by the TUN Judgment Article 116 paragraph 2 of Law Number 5 of 2009 concerning the Second Amendment of Law No. 5 of 1986 concerning State Administrative Court "If after 60 (sixty) working days the court's decision that has obtained permanent legal force as referred to in paragraph (1) is accepted by the defendant not carrying out their obligations as intended in Article 97 paragraph (9) letter a, the decision on the disputed state administration has no legal force anymore". Therefore the Government's actions are not required in carrying out the revocation.

That the potential for a non-performing PTUN decision can occur if the Decision contains obligations as regulated in which constitutes an obligation to issue a New Decree, Article 116 paragraph (3) of Law Number 51 Year 2009 Concerning the Second Amendment to Law Number 5 of 1986 concerning State Administrative Court:

"If the defendant is determined to carry out the obligations referred to in Article 97 paragraph 9 letter $b$ and letter $c$, and then after 90 (ninety) working days it turns out that the obligation is not implemented, then the plaintiff submits an application to the head of court as referred to in paragraph (1) , so that the court orders the defendant to implement the court's decision. Paragraph (4) In the event that a defendant is unwilling to implement a court decision that has obtained permanent legal force, the official concerned is subject to forced efforts in the form of payment of a sum of forced money and/ or administrative sanctions. Paragraph (5) Officials who do not implement a court decision as referred to in paragraph (4) are announced to the local 
print mass media by the clerk since the provisions in paragraph (3) have not been fulfilled. Paragraph (6) In addition to being announced in the local print media as referred to in paragraph (5), the Chairperson of the court must submit this matter to the President as the holder of the highest government authority to order the official to carry out the court's decision, and to the people's representative institutions to carry out the oversight function".

Whereas further concerning employment disputes, it is specifically regulated in Article 117;

"(1) To the extent that the obligations referred to in Article 97 paragraph (11) if the defendant cannot or cannot perfectly carry out the decision a Court that has obtained permanent legal force is caused by changes in circumstances that occur after a court decision has been handed down and/or obtained permanent legal power, it is obliged to notify the Chief Justice as referred to in Article 116 paragraph (1) and the plaintiff. (2) Within thirty days after receiving a notification as referred to in paragraph (1) the plaintiff may submit an application to the Chief Justice of the Court who has sent the award. Courts that have obtained permanent legal force are required to pay the defendant the obligation to pay a sum of money or other compensation they want. (3) The Chair of the Court after receiving the application referred to in paragraph (2) orders to summon both parties to seek agreement on the amount of money or other compensation that must be charged to the defendant. (4) If after an attempt is made to reach an agreement but an agreement cannot be reached regarding the amount of money or other compensation, the Chairperson of the Court shall be determined by being accompanied by sufficient consideration to determine the amount of money or other compensation referred to. (5) Determination of the Chairperson of the Court as referred to in Paragraph (4) may be submitted by both the plaintiff and the defendant to the Supreme Court for re-determination. (6) The decision of the Supreme Court as referred to in paragraph (5), must be obeyed by both parties".

Thus it can be concluded that in order to support the optimization of the implementation of Peratun decisions, the legislators have arranged the role and responsibility of the President to order officials who do not implement Peratun decisions, as well as the oversight function of the DPR against the government is more emphasized in terms of supporting the implementation of decisions Peratun Actually, this norm brings a lot of hope in supporting the implementation of the Peratun decision. As is known, the Presidential and Representative institutions are the largest holders of power in the political constellation of Indonesian law. The Government's position as a Defendant in a TUN dispute in terms of the power 
structure is indeed very vulnerable in carrying out acts of refusal or resistance to the implementation of the Court's decision, specifically the Peratun decision. ${ }^{7}$

Where as the issue of Government Officials who do not implement TUN Court Decisions with the norms set forth above basically provides an opportunity so that the compulsory element can be carried out using the mechanism of giving shame when announced in newspapers and reported to the President, but so far the implementation has not been effective, especially related to the implementation of compensation money which is not regulated in the subsequent implementing regulations, so that the actual material loss suffered by the Plaintiff cannot be recovered, the implementation of the decision which becomes the Plaintiff's source of hope becomes meaningless, only to be a victory on paper. And what causes problems is how if the Defendant is the President, what will be reported to the President later if he does not implement the Peratun decision.

Since the defendant convicted for carrying out the aforementioned obligations is an official, the success in implementing the decision of the State Administrative Court is highly dependent on the authority of the State Administrative Court and the legal awareness of the officials themselves. However, Law Number 5 of 1986 has regulated as well as possible so that the decision of the State Administrative Court can be implemented as it should, if necessary the intervention of the president himself as head of government is possible. ${ }^{8}$

But basically the execution at PTUN emphasizes the principle of self respect and legal awareness of TUN officials regarding the content of judges' decisions to implement them voluntarily without any coercive measures that can be directly felt and imposed by the court against the TUN official concerned. Although it is said that the execution process carried out according to the aforementioned method is the original thought of lawmakers in Indonesia, because such a system is not known abroad. However, these provisions are at the same time a drawback, if it should not

7 Enrico Simanjuntak (n 3).[285].

8 Muhammad Edwin Jr, 'Pelaksanaan Putusan Hakim Pengadilan Tata Usaha Negara Oleh Pejabat Dan Badan Tata Usaha Negara' (Universitas Lampung 2018).[1]. 
be said precisely as a mistake. Because, normativising the law is not enough just to contain the commands and prohibitions. Beyond the prohibition, in particular there must be provisions for sanctions for non-compliance. Legal sanctions to date are still the most powerful tool for maintaining the authority of the law or in other words so that everyone is worthy of the law. The non-compliance of TUN bodies or officials to carry out TUN court decisions can more or less affect the authority of the court, harassment of the judiciary, and it is not impossible if the non-compliance occurs repeatedly, then the community increasingly distrusts the court, and if the community tends to play judges themselves is not an act which stands alone. ${ }^{9}$

The statement above, according to the author is reasonable. Because of this, there is no clarity regarding the mechanism for implementing forced measures in the form of imposing administrative sanctions and forced money payments (dwangsom). As such, the provisions of Article 116 of Law Number 9 of 2004 concerning Amendment to Law Number 5 of 1986 concerning State Administrative Court are non-executable. In fact, it may be that these provisions only become binding norms and have the power of compulsion as text only (toothless tiger), but do not mean anything when faced with a concrete event. ${ }^{10}$

The next issue is whether forced money (dwangsom) can be requested in a lawsuit and decided by a judge, even though there are no implementing regulations? Regarding this question, the Supreme Court has the attitude that states that forced money can be requested in a lawsuit and can be granted and contained in the verdict. The reason is that the government is compelled to immediately make the implementing regulations as instructed by the Law on Peratun, and after three decades of the Peratun Law the implementing regulations have never been issued by the Government. The Supreme Court finally opened the way for the judges so that every lawsuit containing conditional demands included forced money, so that it was possible before the issuance of implementing regulations on forced efforts,

\footnotetext{
9 Lubna (n 6).

${ }_{10}$ Mohammad Afifudin Soleh, 'Eksekusi Terhadap Putusan Pengadilan Tata Usaha Negara Yang Berkekuatan Hukum Tetap’ (2018) 20 Mimbar Keadilan Jurnal Ilmu Hukum.[2].
} 
the judge could apply dwangsom and administrative sanctions based on strong legal arguments as outlined in consideration of the decision. ${ }^{11}$ The still imperfect Peratun Procedural Law has made the implementation of the PTUN Decision still facing obstacles. It is better if we need to review the concept of Acts in violation of government law and the practice of law in a civil suit as an effort to seek justice and comparison with administrative law or State Administrative Law.

In the involvement of the State in association in society there are unlawful acts, which can be carried out by Government Agencies, not by private individuals, such as tax collection actions, actions from the Public Health Service, Police Service actions, Housing Affairs Acts, Immigration Service actions and other actions such as this all fall under the duty of the Government. ${ }^{12}$ The actions of these Government bodies are all according to various rules that were originally set by or by the power of law. In view of this, it can already be said that one of the measures for what is considered appropriate by Government agencies is what the government's actions are in accordance with the purpose of the regulation. In other words: The act of government equipment can be deemed inappropriate in society if the government uses power according to the Government's administrative law for a purpose that is not intended by the Public Law, or in French if there is a "deteournement de pouvoir". ${ }^{13}$ Unlawful acts in civil law in Indonesia are regulated in Article $1365 \mathrm{BW}$.

The doctrine of "acts against the law" in general is the teaching of civil law, why can't the teachings of Onrechtmatige Overheidsdaad also be included as civil law? Just because one of the parties is the ruler? Because the lawsuit in the case of acts against the law by the government comes from individuals who feel their rights and interests have been violated, or feel their wealth has diminished or disappeared by the actions of the authorities, it can be concluded that their unlawful nature is seen

\footnotetext{
${ }^{11}$ Enrico Simanjuntak (n 3).[285].

12 Rwirjono Prodjodikoro, Perbuatan Melanggar Hukum Dipandang Dari Sudut Hukum Perdata (Mandar Maju 2018).[79].

13 ibid.[81].
} 
from the perspective of individuals, so the actions of the authorities as "laederede" is a violation of the rights or interests of individuals, which is also a violation of property law (vermogensrecht). And who asks for protection from the judge for rights and interests and interests (subjectief privaatrecht), it means that he asks to be treated (regulations) Civil law. So Prof. Dr. Sudikno Mertokusumo, SH sees illegal acts by the government as a violation of the rights or interests of individuals. So even though one of the parties is the ruler it becomes a part of civil law. ${ }^{14}$

Article 1365 of the Civil Code does not discriminate between victims who suffer losses due to acts against the law of the authorities. Just as long as the loss suffered by the victim related to the causal relationship (causaliteit) with the actions carried out, both the factual causal relationship (sine qua non) and the approximate cause and effect (proximate cause).${ }^{15}$ Acts against the law by the authorities (Onrechtmatige Overheidsdaad) by civil law can be submitted by the Public or Private Legal Entity by suing the District Court for compensation. Likewise, a PTUN decision that is not obeyed by the authorities can be brought against the Ruling Act against the Ruler with a simple evidentiary mechanism in the form of non-compliance in carrying out a court decision (res judicata) is an act against civil law that can be assessed for compensation in practice.

That this can be seen in the practice of a case against Government Law with a lawsuit in the General Court between the Head of Seketi Village, Balong Bendo District, Sidoarjo Regency, represented by Seger Purwanto (Defendant) against Solihin as a former Seketi Village Official, Balong Bendo District, Sidoarjo Regency (Plaintiff). . With the dispute object of the Decree of the Head of Seketi Village, Balongbendo Subdistrict, Sidoarjo Regency Number: 141/03/404.5.11.04/2012 dated August 1, 2012 concerning Dismissal with respect to other Village Officials with the position of Head of Guyangan Hamlet Seketi Village, Seketi Subdistrict, Balongbendo District, Sidoarjo Regency, due to his term of office has expired.

${ }^{14}$ Sudikno Mertokusumo, Perbuatan Melawan Hukum Oleh Pemerintah (Cahaya Atma Pusaka 2014).[6].

${ }^{15}$ Munir Fuady, Perbuatan Melawan Hukum (Citra Aditya Bhakti 2002).[6]. 
In this case dismissed is the Plaintiff who was previously appointed as a Village Official based on the Decree of the Seketi Village Chief Number: 141/02 /404.5.11.04/2002 dated June 18, 2002 concerning Ratification of the Seketi Village Officials Balongbendo District Sidoarjo Regency is 10 (ten) years based on Regulation Sidoarjo Regency Region Number 4 of 2000, the Defendant was legally right to issue the object of the dispute because the time period was up then the Plaintiff was dismissed but in the trial of case number No. 70/B/2013/PT.TUN. Sby on February 21, 2014 jo case: 123/G/2012/PTUN. Sby On June 24, 2013, the Plaintiff was won and Defendant was ordered to Decide to revoke the object of the dispute and issue a new Decree based on Sidoarjo District Regulation Number 10 of 2006 (with tenure 15 years) The Plaintiff, but the Defendant was unwilling to carry out the decision on the grounds that the Plaintiff's position had been filled with new village apparatus as a result of the selection, the Defendant's silence forced the Head of the Surabaya TUN Court to issue a Surabaya Administrative Court Number: 123/PEN.EKS/2012/PTU. SBY dated 21 February 2014, in item 3 written that does not render the Decision of the Surabaya State Administrative High Court with Permanent Legal Strength and the Decree of Execution of the Surabaya State Administrative Court is an act against the law, Solihin/Plaintiff then submits a lawsuit against the law to the Court The State of Sidoarjo with the position of Seger Purwanto is in the position of being in the position $u$ The Head of Seketi Village as Defendant, with case register number: 86/Pdt.G/2014/PN.Sda in the first level the Plaintiff was defeated, and the Plaintiff Plaintiff to the Surabaya High Court, with case register Number: 91/PDT/2015/PT. Sby, at the Appellate Level the Plaintiff was won with consideration of the Decision.

"Considering that the Defendant proved to have dismissed the Plaintiff as the Head of Guyangan Hamlet and the appointment of Brother Sodik (Participant and Defendant 2) as Head of the Guyangan Hamlet also connected with the Decree of the High Court of State Administration on June 182013 case number 70/B/2013/PT.TUN Sby, which declared null and ordered revoking the Decree of the Village Head (Defendant) No: 141/63/404/5.11.04/2012 dated August 1, 2012 concerning Dismissal with the Solihin Ormat ( Plaintiff Plaintiff) as Head of the Village and ordered the Defendant to make a letter The new decision to appoint Solihin as Head of Guyangan Hamlet in accordance 
with Regional Regulation 10 of 20016 apparently was not carried out by the Defendant, the Defendant's actions were detrimental to the rights of the Plaintiffs, proven according to the law of the Defendants and Participants of the Defendant had done Acts Against the Law ... The Defendants and Also involved is the Defendant to pay material losses in the form of income allowances for the Village Government for 22 (twenty two) months worth Rp. $48.180,000$... etc".

at the level of the SUPREME COURT, Case Number: 110K/Pdt/2016 April 13, 2016 reinforces the Appeal Decision. (From the construction of the lawsuit, the Plaintiff filed a civil suit to the individual, namely Seger Purwanto et al, not suing his position, so that when the Cassation verdict had broken up the District Court had taken the initial steps to execute the Defendant's home, Seger Purwanto. Reapplication cancels the cassation decision).

Against TUN Case Number: 70/B/2013/PT.TUN. Sby on February 21, 2014 jo case: 123/G/2012/PTUN.Sby On June 24, 2013, a review was submitted to the Supreme Court of Indonesia on March 12, 2015 by the Defendant and was registered in the Supreme Court in Case Number: 72PK/TUN/2015 with its decision on August 3, 2015 that Cancels the Decree of the Surabaya State Administrative Court Number 70/B/2013/PTTUN.Sby. June 24, 2013 and in its legal considerations.

"That the Surabaya State Administrative High Court has erred in evaluating the evidence, because the Plaintiff was appointed based on Sidoarjo regency Regulations Number 4 of 2000 Concerning Nomination, Election and Appointment Procedure of Village Officials with a tenure of 10 ( ten) years from June 18, 2002; That Sidoarjo Regency Regulation Number 7 of 2001 concerning First Amendment of Sidoarjo Regency Regulation No. 4 of 2000 concerning Procedures for Nominating, Election and or Appointment of Village Apparatus does not apply to the Plaintiff because the Regulation is valid from 12 July 2002 so that the Plaintiff's term of office is 10 (ten) years as decided properly by the State Administrative Court".

This TUN PK Decision is used as evidence in a civil case by submitting a Judicial Review to the Supreme Court and terminated in Case Review Number: 151PK/PDT/2018 by canceling the SUPREME COURT DECISION, Number: 110K/Pdt/2016 April 13, 2016 jo Case Number: 91/PDT/2015/PT.Sby on 30 June 2015 and stated the lawsuit was DENIED, and in its consideration on the copy of Decision case 151PK/PDT/2018 on page 6 paragraphs 5 and 6 which read. 
"That the Surabaya High Court's decision was upheld by h Judect Yuris has based on Surabaya State Administrative Court Decision Number 70/B/2013/ PTTUN Sby, which granted the Plaintiff's claim in the State Administration case but it turns out that Surabaya State Administrative High Court Number: 70/B/2013/PTTUN Sby has canceled with a Judgment Review Number: $72 \mathrm{PK} / \mathrm{TUN} / 2015$. Therefore, the consideration that states that the Defendant has committed an illegal act in a quo civil law has lost its legal basis".

But the Defendant's defeat caused the Plaintiff to submit a Review of the Reinforcement Decision above and there is still no decision to date. That the Plaintiff in the case above should procedurally include a claim for compensation and or Compensation in his claim in Peratun in accordance with PP 43 of 1991 concerning Compensation and its Procedure for Implementation in State Administrative Court as stipulated in this Government Regulation

"what is meant by: 1. Replace Loss is payment an amount of money to a person or a civil legal entity at the expense of the State Administration Agency based on the decision of the State Administrative Court because of the material loss suffered by the plaintiff. 2. Compensation is the payment of an amount of money to a person at the expense of the State Administration Agency because the decision of the State Administrative Court in the area of employment cannot or is imperfectly carried out by the State Administration Agency." Sources of compensation are charged to the APBN/APBD in Article 2" (1) Compensation which is the responsibility of the Central State Administration Agency, is charged to the State Budget (APBN). (2) A compensation which is the responsibility of the Regional State Administration Agency, is charged to the Regional Revenue and Expenditure Budget (APBD)." Regarding the amount of value regulated in article 3" (1) The amount of compensation that the plaintiff can obtain at least Rp. 250,000, - (two hundred fifty thousand rupiah), and a maximum of Rp. 5,000,000 (five million rupiahs), taking into account the real situation. "Article 14" (1) The amount of compensation referred to in Article 10 is at least Rp. 100,000, - (one hundred thousand rupiah) and a maximum of Rp. 2,000 000, - (two million rupiahs), taking into account the real situation".

The value is indeed not large because it was formulated in 1991 so that the Plaintiffs may be too small in value. Article 17 Government Regulation Number 43 of 1991 jo. Article 5 paragraph (1) of the Decree of the Minister of Finance No.1129 of 1991 stipulates that administrative sanctions can be imposed on the relevant State Administration Agency or Official, but the imposition of administrative sanctions is limited only in relation to negligence resulting in the state paying compensation. 
So it has nothing to do with actions that do not want to carry out court decisions that have permanent legal force (inkracht van gewijsde). ${ }^{16}$ From the example of the case, it can be said that Compliance Complaints in the form of material losses can be made on the TUN Court's Decision which has permanent legal force for a PMH lawsuit personally not because of his position or a lawsuit because of his position at the District Court due to not implementing the PTUN Decision.

Even if forced payment of money (dwangsom) in relation to the implementation of the execution of the State Administrative court decision is applied, Indroharto emphasized that for example forced money was applied, it must be remembered that: - Property used for public purposes cannot be placed in the confiscation of execution;Obtaining power to carry out on their own at the expense of the government (executable party) would be contrary to the principle of legality which says that acting or deciding something based on public law can only be done by a TUN Agency or Position that is authorized or based on the provisions of the legislation; Taking away the freedom of those who hold government positions as a means of coercion will result in severe reflections on the course of government; The government is always considered able and able to pay for solvables. Based on the description above it can be concluded that the application of forced money payments (dwangsom) is part of the procedural law of the State Administrative Court according to Law Number 5 of 1986 in conjunction with Law Number 9 of 2004 should be studied in depth. Moreover, it was alleged that the procedural law of the State Administrative Court was not well understood, there was no common perception, especially regarding the principles of administrative law, and also no less important was the awareness of the State Administration Officer in complying with the Decree of the State Administrative Court. ${ }^{17}$

In the comparison of progressive breakthroughs from various countries, the writer tries to see from the conception that is in France. Institutions or officials

${ }^{16}$ Ladju Kusmawardi, 'Penerapan Sanksi Administratif Dalam Putusan Perkara Tata Usaha Negara Di Pengadilan Tata Usaha Negara Semarang' (2018) 14 Jurnal Law Reform.[104-114].

17 Lubna (n 6). 
who are late in executing are given sanctions and threats by paying money on a daily basis. The longer the delay the greater the amount of money to be paid later (astreinet). They also feared reprimands from Conseil D 'Etat. This body is very influential in France. They are afraid that if they do not obey these warnings or warnings, the budget plans submitted in the following periods will be boycotted or disapproved. The same thing in Egypt was overcome by including criminal sanctions that did not comply with execution. They are threatened with criminal sanctions or fines. However, the inclusion of criminal sanctions on the application of administrative law seems less democratic. In the Law on "Contemt of the court", provisions should be formulated that authorize judges to issue decisions that require paying a sum of money (forced money), carrying out certain obligations and partly (civil contemt of court) for parties those who do not want to carry out the court's decision. Clear court decisions must be respected, implemented and should not be interpreted again for the sake of the rule of law. ${ }^{18}$

\section{After the Entry Into Force of Law Number 30 the Year 2014 Regarding Government Administration.}

The problem of the TUN dispute originates from the object of the dispute in the form of a State Administration Decree, in the case of the Administrative Dispute the KTUN is tested in addition to Article 53 of Law Number 9 of 2004 Concerning Amendments to Law Number 5 of 1986 concerning State Administrative Court that reads

"(1 ) A person or legal entity that feels that his interests have been impaired by a State Administration Decree can file a written claim to the competent court that contains demands that the disputed State Administration Decree be declared null or void, with or without a claim for compensation and/ or rehabilitated (2). Reasons that can be used in a lawsuit as referred to in paragraph (1) are; a. The State Administrative Decision that is sued is contrary to the applicable laws and regulations, $b$. The State Administrative Decision sued contradicts the general principles of good governance".

\footnotetext{
18 ibid.[164].
} 
Also tested with Articles 70 and 71 of Law Number 30 the Year 2014 Concerning Government Administration a Decree was declared to be Unauthorized Acts Article 70:

(1) An illegal decision and/or action if:

a. made by an unauthorized Agency and/or Government Official;

b. made by the Agency and/or Government Official that exceeds its authority; and/or

c. made by the Agency and/or Government Official who acts arbitrarily.

(2) The legal consequences of the Decree and/or Actions as referred to in paragraph

(1) become:

a. not binding since the said Decree and/or Action is stipulated; and

b. all legal consequences are never considered existent.

(3) In the event that a decree resulting in payment of state money is declared invalid, the Agency and/or Government Official must return the money to the state treasury.

Unauthorized actions bring legal consequences that the decree was considered non-existent (Cancel by law) because of a defective authority. With severe legal consequences if with the issuance of the KTUN there is use and financing of the State Budget, the official personally returns the financial to the state treasury.

An action that can be canceled because:

Article 71

(1) Decisions and/or actions can be canceled if

a. there is a procedural error; or

b. there is a substance error.

(2) Legal consequences of Decisions and/or Actions as referred to in paragraph (1): a. not binding from the moment it is canceled or remains valid until the cancellation; and

b. ends after cancellation

(3) Decisions on cancellations are made by Government Officials and/or Official Bosses by stipulating and/or making new decisions and/or Acting Government Officials or based on court orders.

(4) The stipulation of a new decree as referred to in paragraph (3) shall be an obligation of the Government Official.

(5) Losses arising from decisions and/or actions canceled are the responsibility of the Agency and/or Government Official 
Decisions that are flawed in procedure and substance become null and void will bring legal consequences. The decision becomes invalid since it is revoked or declared null and void for a period of time by the TUN Judgment Article 116 paragraph 2 of Law Number 5 of 2009 Concerning the Second Amendment of Law No. 5 of 1986 Concerning State Administrative Court.

"If after 60 (sixty) working days the court's decision that has obtained permanent legal force as referred to in paragraph (1) is accepted by the defendant not carrying out its obligations as referred to in Article 97 paragraph (9) letter a, administrative decision the disputed country has no legal power anymore".

UUAP is a legal instrument aimed at the AP.UU Peratun is the basis of law enforcement in material administrative law. The Peratun Law adheres to the view that the Perdilan body through the Chair of the Court has the duty and responsibility to ensure compliance with the Peratun Decision. On the other hand, the UUAP understands that the problem of compliance with the Peratun Decision is one of the issues in the context of the supervision and fostering of the UUAP. The intersection of authority between the Peratun institution and the executive power in implementing the Peratun decision raises its own legal problems. The problem is, among others, that the Judiciary believes that the provisions governing the obligations of the TUN Agency or Officer to implement the Court's Decision are in article 72 paragraph (1) UUAP.

Article 72

(1) Government Agencies and/or Officials are obliged to implement valid Decisions and/or Actions and Decisions that have been declared invalid or canceled by the Court or the relevant official or supervisor concerned.

(2) Provisions regarding the procedure for returning as referred to in Article 70 paragraph (3) and the responsibilities of Government Agencies and/or Officers due to losses arising from Decisions and/or Actions as referred to in Article 71 paragraph (5) shall be regulated in a Government Regulation.

Violations of article 72 paragraph (1) of the UUAP are subject to moderate administrative sanctions as determined in article 80 paragraph (2) of the UUAP and 
are associated with article 9 number 2 PP No. 48 of 2016 concerning Procedures for Imposing Administrative Sanctions for Government Officials. The form of moderate administrative sanctions is as stipulated in Article 81 paragraph (2) UUAP, namely (a) forced payment of money and/or compensation, (b) temporary dismissal by obtaining office rights or (c) temporary dismissal without obtaining title rights. ${ }^{19}$

Moderate administrative violations or severe administration constitutes indirect administrative sanctions, meaning violations of the provisions that are threatened by moderate or severe administrative sanctions through the mechanism specified in PP No. 48 In 2016, which began with a public complaint to APIP, then APIP checked, after being examined by APIP in a closed manner then sanctions were imposed by the supervisor of the official concerned. Another problem concerns the threat of sanctions for AP apparatuses who do not implement the provisions of article 72 paragraph (1) UUAP is related to the substance of the sanction itself Article 7 letter (f) PP Number 48 Year 2016 states "moderate administrative sanctions as referred to in article 4 letter b are imposed on government officials if they do not: (letter f) implement Decisions and/or legal actions and Decisions that have been declared invalid or canceled by the Court or the relevant Officer or superior concerned". Provisions of Article 9 number 2 PP No. 48 of 2016 concerning Procedures Imposition of Administrative Sanctions for Government Officials. The form of moderate administrative sanctions is as stipulated in Article 81 paragraph (2) of the UUAP, namely: (a) Forced payment and/or compensation (b) temporary termination by obtaining office rights; or (c) temporary termination without obtaining title rights. ${ }^{20}$

That the mechanism for implementing the TUN Court's Decision is subject to moderate administrative sanctions, in the form of forced payment of money and/ or compensation, temporary termination by obtaining office rights or, temporary termination without obtaining office rights subject to cumulative and alternative

${ }_{19}$ Enrico Simanjuntak, Hukum Acara Pradilan Tata Usaha Negara Transformasi Dan Refleksi (Sinar Grafika 2018).[288].

${ }^{20}$ ibid.[289]. 
imposed. Regarding dwangsom and compensation, it seems that it has not been specifically regulated regarding the mechanism and amount of value that must be imposed in the PP, but if we refer to PP No. 43/1991, it is only used in filing a lawsuit, not related to not carrying out the PTUN Decision and even then it seems that it cannot be used as guidelines for the small amount of value and do not meet the sense of justice for the material loss suffered by the Plaintiff at this time.

That some time ago the Supreme Court Regulation No. 2 of 2019 was issued concerning Guidelines for Dispute Resolution of Government Actions and Authority to Prosecute Unlawful Acts by Government Agencies and/or Officers (Onrechtmatige Overheidsdaad) on August 9, 2019, which in essence regulates Article 2 paragraph 1 "The Case of Violating the Law by a Government Agency and or Officer (Onrechtmatige Overheidsdaad) is the authority of the State Administrative Court" thus the District Court / General Court has no authority in adjudicating the act of violating the Government Law (absolute competence), the grace period is 90 days since the Government action is carried out, Article 5 paragraph 2 "In the event that the lawsuit is granted, the Court may require the Government Administration Officer to a, take government action, b. Not taking government action and c stopping Government action." Article 5 paragraph 3 "the obligation referred to in paragraph 2 can be accompanied by the imposition of rehabilitation and or compensation" however in this Perma the compensation formula does not seem to be clearly regulated in relation to the value of the material loss which, and with what value and is charged to the state budget/ regional budget? With this regulation, it is no longer possible for officials who do not comply with the Peratun decision to be filed as Defendants in a civil compensation suit (onrechtmatige overheidsdaad) to the District Court.

With the expansion of the authority to adjudicate cases that are factual, it is believed that some cases of onrechtmatige overheidsdaad which have been the jurisdiction of the General Courts will turn to Peratun. Meanwhile in the case of Onrechtmatige Overheidsdaad compensation is possible on the basis of losses that are material and immaterial losses. Therefore, in cases of examining the validity of 
factual actions in government administration, a clear and firm legal framework is needed to determine the values of losses both material and immaterial in nature as long as they are practiced by the general court. ${ }^{21}$

Another legal obstacle is the TUN Officer as the defendant who must implement the TUN Court's Decision. Until now the implementation of the TUN Court's Decision was handed over by the volunteerism of the TUN Officer to carry it out, because the TUN Court's Decision lacked coercive power. Disobedience of TUN Officials to implement the TUN Court's Decision results in PTUN not functioning enough to provide maximum legal protection for justice seekers. If the TUN Officer does not implement the TUN Court's Decision, the plaintiff or justice seeker will only win on paper and cannot enjoy his victory so that his sacrifice to sue the PTUN will be in vain. ${ }^{22}$

The obstacles in implementing the execution of PTUN decisions are 1) The absence of a special executorial agency or sanctioning institution that functions to implement the decision. This is different from other judicial institutions such as the General Courts which have forced institutions, namely real executions by the Registrar under the leadership of the Chief of the Court for civil cases (Article 195 to Article $208 \mathrm{HIR}$ and Article $1033 \mathrm{Rv}$ ), and there is a prosecutor as executor of the Criminal verdict (Article 270 Criminal Procedure Code). In military court is a military prosecutor who is obliged to execute the decision of a military judge. Religious Courts, according to the provisions of articles 95, 98 and 103 of Law No. 7 of 1989 has also been able to carry out by force (Execution) of the decision and decision including carrying out all forms of confiscation (beslag). Meanwhile, with the State Administrative Court, what forced institutions can be applied if all stages of execution, namely reprimand through superiors are hierarchically up to the presidential level, the TUN Officer still does not implement them? Until now no. this is the only Judiciary in the judicial system in Indonesia (of the four

\footnotetext{
${ }^{21}$ ibid.[291].

${ }^{22}$ Francisca Romana Harjiyatnidan Sunarya Raharja, 'Fungsi Peradilan Tata Usaha Negara Dalam Menyelesaikan Sengketa Lingkungan’ (2014) 26 Mimbar Hukum.[273].
} 
neighborhoods), which has no forced institutions. For this reason, it is not surprising that many decisions have not been implemented. 2) The low level of awareness of TUN officials in obeying TUN court decisions. TUN 30 Rasyid official, Roihan A. (2001). Religious Court Procedure Law, Jakarta: Raja Grafindo Persada, often disobeying the law, because usually a person obeys the law because he is afraid of sanctions that will be imposed if he violates the law or because he feels his interests will be guaranteed if he obeys the law, or because he feels applicable law in accordance with the values that apply in him. In this case, the party that loses the dispute will certainly feel that his interests are not guaranteed if he obeys the TUN court's decision, so he prefers not to comply with the court's decision. The absence of sanctions also makes TUN officials not afraid if he does not carry out the court's ruling. The existence of personal interests of the official existence of TUN decisions issued and the weak level of legal awareness of the Agency or The TUN official has a great influence on whether or not the decision of the Judge of Peratun is obeyed, because normatively the execution of the decision of the Judge of Peratun relies more on the willingness of the relevant Officer to carry out it (floating execution). By only relying on willingness, of course many officials are not willing to have to fulfill a decision, so choose not to obey the decision. ${ }^{23}$

As a result of the Law not realizing justice in the implementation of TUN court decisions by government officials, the actions of these government officials are arbitrary. ${ }^{24}$

\section{Conclusion}

That the Government in carrying out its duties can be sued if the action is not based on authority, procedures and substance in accordance with the provisions of the legislation. And at the same time it must be in accordance with the General

${ }^{23}$ Dezonda Rosiana Pattipawae, 'Pelaksanaan Eksekusi Putusan Pengadilan Tata Usaha Negara Di Era Otonomik’ (2019) 25 SASI Fakultas Hukum Universitas Pattimura.[92].

24 Saartje Sarah Alfons, 'Konsekuensi Yuridis Terhadap Diabaikannya Pelaksaan Putusan Pengadilan Tata Usaha Negara Yang Telah Memiliki Kekuatan Hukum Tetap' (2018) 24 SASI Fakultas Hukum Universitas Pattimura.[179]. 
Principles of Good Governance. By carrying out their duties in accordance with the rules to minimize actions that violate the law.

In a TUN dispute the Government is often the Defendant, several times it has been proven wrong based on the Peratun Decision which has permanent legal force (Inkracht Van Gewijsde) and is not in accordance with the provisions of the legislation and or AAUPB, the Government's obligation in this case is to implement the Decision which is Res judicata and that's the law. However, the Government in certain cases deliberately did not implement the Peratun decision for a certain reason, however, if a Peratun Decision has permanent legal force, then there is actually no more reason not to obey it. At present UUAP provides moderate administrative sanctions for anyone who does not implement the Peratun Decision, the medium sanction is expected to make the Officials implement the Decision voluntarily.

Compensation seems unclear about the form and value that must be stated in a decision considering PP 43 of 1991 concerning Compensation and Procedure for Implementation in State Administrative Court whose value is no longer in line with the current conditions, in terms of compensation and dwangsom as a result of not implementing a decision, it turns out that there is also no clarity regarding the regulation of the amount and value that must be determined. If in practice it is possible for a Lawsuit to Violate Civil Law due to non-implementation of the PTUN decision and the value of material losses can be properly calculated in a decision, but since the issuance of Supreme Court Regulation No. 2 of 2019 it seems that the PMH lawsuit to the General Court has not been able to be carried out anymore. That for the development of the system in Peratun especially related to material losses both in filing a TUN lawsuit and the consequences of not implementing the PTUN Decision, provisions must be formulated as to how the compensation is formulated both in terms of the value and source of payment accordingly, as well as the mechanism for executing the award. bearing in mind the execution of the Government or Officials so that the interests of the public, individuals or legal entities are protected, and such enforcement would be as applicable in the General Court. 


\section{Bibliography}

Dezonda Rosiana Pattipawae, 'Pelaksanaan Eksekusi Putusan Pengadilan Tata Usaha Negara Di Era Otonomik' (2019) 25 SASI Fakultas Hukum Universitas Pattimura.

Enrico Simanjuntak, Hukum Acara Pradilan Tata Usaha Negara Transformasi \& Refleksi (Sinar Grafika 2018).

—_, Hukum Acara Pradilan Tata Usaha Negara Transformasi Dan Refleksi (Sinar Grafika 2018).

Francisca Romana Harjiyatnidan Sunarya Raharja, 'Fungsi Peradilan Tata Usaha Negara Dalam Menyelesaikan Sengketa Lingkungan’ (2014) 26 Mimbar Hukum.

Ladju Kusmawardi, 'Penerapan Sanksi Administratif Dalam Putusan Perkara Tata Usaha Negara Di Pengadilan Tata Usaha Negara Semarang' (2018) 14 Jurnal Law Reform.

Lubna, 'Efforts To Force The Implementation Of The Court Ruling The Country In Providing Legal Protection To The Community' (2015) 168 Ius Kajian Hukum Dan Keadilan.

Mohammad Afifudin Soleh, 'Eksekusi Terhadap Putusan Pengadilan Tata Usaha Negara Yang Berkekuatan Hukum Tetap' (2018) 39 Mimbar Keadilan Jurnal Ilmu Hukum.

_- 'Eksekusi Terhadap Putusan Pengadilan Tata Usaha Negara Yang Berkekuatan Hukum Tetap' (2018) 20 Mimbar Keadilan Jurnal Ilmu Hukum.

Muhammad Edwin Jr, 'Pelaksanaan Putusan Hakim Pengadilan Tata Usaha Negara Oleh Pejabat Dan Badan Tata Usaha Negara' (Universitas Lampung 2018).

Munir Fuady, Perbuatan Melawan Hukum (Citra Aditya Bhakti 2002).

Paulus Efendi Lotulung, Lintasan Sejarah Dan Gerak Dinamika Peradilan Tata Usaha Negara (PERATUN) Di Mata Paulus Effendi Lotulung (Salemba Humanika 2013).

Rwirjono Prodjodikoro, Perbuatan Melanggar Hukum Dipandang Dari Sudut Hukum Perdata (Mandar Maju 2018).

Saartje Sarah Alfons, 'Konsekuensi Yuridis Terhadap Diabaikannya Pelaksaan Putusan Pengadilan Tata Usaha Negara Yang Telah Memiliki Kekuatan 
Hukum Tetap' (2018) 24 SASI Fakultas Hukum Universitas Pattimura.

Sudikno Mertokusumo, Perbuatan Melawan Hukum Oleh Pemerintah (Cahaya Atma Pusaka 2014).

Wirjono Projodikoro, Asas-Asas Ilmu Negara Dan Politik(Eresco 1971).

HOW TO CITE: Aris Saputro, 'Payment of Compensation for Officials Who Did Not Implement the Decision of the State Administrative Court' (2020) 35 Yuridika. 
--This page is intentionally left blank-- 